\title{
INHERITANCE OF DISC FLOWER COLOR IN Helianthus petiolaris
}

\author{
Gutierrez, A. ${ }^{*}$, Delucchi, C. ${ }^{2}$ and Poverene, M. $^{1}$ \\ ${ }^{1}$ Departamento de Agronomía, Universidad Nacional del Sur and \\ CERZOS-CONICET, 8000 Bahía Blanca, Argentina \\ 2 INTA Estación Experimental Pergamino, ruta 32 km 4,5 B270oWAA Pergamino \\ Received: June 16, 2008 \\ Accepted: June 02, 2009 \\ SUMMARY \\ Disc flowers of Helianthus petiolaris (Asteraceae) are usually purple red \\ due to anthocyanin pigments in corolla lobes, style and stigma. However, yel- \\ low-flowered plants are occasionally found. The inheritance of this trait was \\ studied through crosses between different phenotypes and the results indi- \\ cated that flower color is controlled by two genes with complementary action, \\ both loci being dominant and independently inherited. This agrees with results \\ obtained in cultivated sunflower, $H$. annuus, where one to three dominant \\ genes have been proposed for anthocyanin expression in different organs.
}

Key words: anthocyanin, complementary genes, wild sunflower

\section{INTRODUCTION}

Helianthus petiolaris Nutt. (Asteraceae), known as the prairie sunflower, is an annual, diploid $(\mathrm{x}=17)$, and highly self-incompatible species (Heiser et al., 1969). Native to North America, it was probably introduced in Argentina as contaminant in forage seed lots and was first described in the field by Covas (1966). At present, it has established itself in the central part of the country and is widespread on sandy soils.

H. petiolaris is well-known as source of male sterility and fertility restoring genes, which has allowed a massive production of sunflower hybrid seed (Leclercq, 1969; but see Rieseberg et al., 1994). It is also a major source of genes for Verticillium wilt (Verticillium dahliae), downy mildew (Plasmopara halstedii) and rust (Puccinia helianthii) resistance, tolerance to sunflower moth (Homoeosoma electellum) and genetic improvement of cultivated sunflower (Jan and Seiler, 2007). Phenotypic genetic markers are useful for marker-assisted selection in the field and despite intense research, only a few have been identified in sunflower and its rela-

* Corresponding author: Fax 0054291 4595127; e-mail: aguti@criba.edu.ar 
tives (Gentzbittel et al., 1999; Gedil et al., 2001 and Carrera et al., 2002). Most studies in this species refer to hybridization with $H$. annuus (Heiser, 1947; Rieseberg et al., 1995; Rieseberg et al., 1999; Buerkle and Rieseberg, 2001 and Poverene et al., 2004) but scanty information are available about specific traits inheritance.

Studies on disc flower color inheritance have been carried out in the cultivated sunflower, $H$. annuus. The presence of anthocyanin in different organs is expressed as a single dominant trait (Leclercq, 1968). A gene with pleiotropic effects seems to be responsible for color in corolla lobes, stigma, stems and petioles (Fick, 1976) whereas two or three independently inherited genes with complementary effect have been proposed for the stigma color (Luczkiewicz, 1975 and Joshi et al., 1994). Complementation is the production of the wild type phenotype when two parents contribute haploid genomes bearing different recessive mutations. The purple color in stems, petioles and bracts tips is dominant to the green color and has been assigned to two complementary genes (Deveraja and Shanker, 2005).

Among annual Helianthus species, disc flowers present different colors: purple in $H$. agrestis, $H$. debilis sp. silvestris, $H$. exillis and $H$. praecox; reddish - purple in $H$. bolanderi, $H$. nievus sp. tephrodes and $H$. niveus sp. niveus; deep purple in $H$. paradoxus and $H$. argophyllus, although this latter can also present light reddish to purple flowers (Rogers et al., 1982). Disc flowers in $H$. petiolaris are usually purple red due to the presence of anthocyanins in corolla lobes, style and stigma. However, yellow flowers without anthocyanins are occasionally found in natural populations (Heiser, 1961; Rogers et al., 1982) although the genetic control of this trait is still unknown.

In many other plant species, flower color depends on dominant genes for pigment synthesis showing epistatic interaction (Sreevalli et al., 2002; Pahlavani et al., 2004) and complementary action (Wilson and Hudson, 1978 and Imrie and Hutton, 1978). In cultivated sunflower a single dominant gene has been found (Fick, 1976 and Mosjidis, 1982) although there are variations in color shade and tint.

The goal of this work was to study disc flower color inheritance in $H$. petiolaris. We proposed that red color is controlled by dominant alleles responsible for anthocyanins in two independently inherited loci, while recessive alleles produce yellow flowers, without anthocyanins. Thus, several crosses between these phenotypes were made to determine how the trait is inherited.

\section{MATERIALS AND METHODS}

In this study, plants with yellow-disc flowers were collected in a wild population established in a vacant field lot near Highway 1, km 256, in La Pampa province. The seed was sown in the experiment field of the Agronomy Department in Bahía Blanca, where this species does not grow naturally. In 2004, when the seeds from open pollinated plants with yellow flowers were harvested, a plot was established in 
the same field. Immature heads were covered with bags to make crosses among different flower colored plants: red $\times$ red, yellow $\times$ yellow, red $\times$ yellow and yellow $\times$ red. Consequently, ten crosses of each type were made and the following year the progenies obtained in this way were classified according to disc flower color. In order to verify self pollination, a number of heads were bagged.

In 2005 , plants from the red $\times$ yellow and yellow $\times$ red crosses were pollinated with yellow-colored plants, as a test-cross. Each year, seedlings were raised in the greenhouse and about one month later they were transplanted to the experiment field. The immature heads were covered with polyamide bags before the ligules were visible, to make the crosses. Also, the bracts (phyllaries) and ligules were trimmed to facilitate pollination. When the stigmas appeared receptive, pollen of the chosen parent was applied with a thin brush for 3-4 consecutive days, maintaining the heads covered until seed maturity.

Chi-square and G tests were used for testing the goodness-of-fit of the observed and expected frequencies of phenotypic classes.

\section{RESULTS AND DISCUSSION}

Four viable seeds were obtained among 942 from five self-pollinated heads which reached maturity, with a mean of 187.6 aborted seeds per head and less than 1 viable seed per head. Thus, it was considered that seed from selfing would not significantly bias the expected phenotypic ratio in crosses.

In the proposed inheritance model, the red pigment of disc flowers would be controlled by dominant alleles in two loci, so the red flowers would have any of the following genotypes: $A_{1} A_{1} A_{2} A_{2}, \quad A_{1} A_{1} A_{2} a_{2}, \quad A_{1} A_{1} a_{2} a_{2}, \quad A_{1} a_{1} A_{2} A_{2}, \quad A_{1} a_{1} A_{2} a_{2}$, $A_{1} a_{1} a_{2} a_{2}, a_{1} a_{1} A_{2} A_{2}$, and $a_{1} a_{1} A_{2} a_{2}$ while the yellow flowers would have only one genotype, $a_{1} a_{1} a_{2} a_{2}$. According to this hypothesis, all the plants in the 2004 plot that had been obtained from open pollinated yellow plants had at least two recessive alleles, $a_{1}$ and $a_{2}$, being the possible genotypes $A_{1} a_{1} A_{2} a_{2}, A_{1} a_{1} a_{2} a_{2}, a_{1} a_{1} A_{2} a_{2}$, and $a_{1} a_{1} a_{2} a_{2}$ in equivalent ratios. It was estimated that all the genotypes corresponding to the red flower phenotype occurred in similar frequencies, thus assuming that natural selection would not favor any particular genotype.

Red $\times$ red crosses should involve all the possible combinations of the genotypes mentioned above, except for the last one. Consequently, considering an independent segregation of the two loci, $A_{1} a_{1} A_{2} a_{2} \times A_{1} a_{1} A_{2} a_{2}, 2\left(A_{1} a_{1} A_{2} a_{2} \times A_{1} a_{1} a_{2} a_{2}\right)$, $2\left(\mathrm{~A}_{1} \mathrm{a}_{1} \mathrm{~A}_{2} \mathrm{a}_{2} \times \mathrm{a}_{1} \mathrm{a}_{1} \mathrm{~A}_{2} \mathrm{a}_{2}\right), \quad \mathrm{A}_{1} \mathrm{a}_{1} \mathrm{a}_{2} \mathrm{a}_{2} \times \mathrm{A}_{1} \mathrm{a}_{1} \mathrm{a}_{2} \mathrm{a}_{2}, \quad 2\left(\mathrm{~A}_{1} \mathrm{a}_{1} \mathrm{a}_{2} \mathrm{a}_{2} \times \mathrm{a}_{1} \mathrm{a}_{1} \mathrm{~A}_{2} \mathrm{a}_{2}\right), \quad$ and $\mathrm{a}_{1} \mathrm{a}_{1} \mathrm{~A}_{2} \mathrm{a}_{2} \times \mathrm{a}_{1} \mathrm{a}_{1} \mathrm{~A}_{2} \mathrm{a}_{2}$ would produce a 55 red : 9 yellow ratio. In the same way, red $\times$ yellow and reciprocal crosses involving $A_{1} a_{1} A_{2} a_{2}, A_{1} a_{1} a_{2} a_{2}$, and $a_{1} a_{1} A_{2} a_{2}$ genotypes for red flowers would produce a 5 red : 3 yellow ratio.

The frequencies of phenotypes observed in the 2004 crosses red $\times$ red, yellow $\times$ yellow, and red $\times$ yellow fit the expected ratios, whereas progeny of yellow $\times$ red crosses showed a deviation (Table 1 ). 
The departure from the frequency expected in the 2004 yellow $\times$ red crosses results could be ascribed to a failure in seed set caused by environmental factors, as crosses were made in the field, not in the greenhouse. Besides, a failure in manual pollination cannot be ruled out. Although $H$. petiolaris is highly incompatible, self-pollination has been observed under mixed loads of heterospecific pollen (Desrochers and Rieseberg, 1998). However, this situation may have taken place due to the presence of $H$. annuus plants in the experiment field.

Table 1: Observed and expected progenies for red $(\mathrm{R})$ and yellow $(\mathrm{Y})$ disc flowers in several crosses of Helianthus petiolaris

\begin{tabular}{lcccccc}
\hline \multirow{2}{*}{ Cross } & \multicolumn{2}{c}{ Observed frequency } & \multirow{2}{*}{ Expected frequency $R: Y$} & $\chi^{2}$ & $P$ & G \\
\cline { 2 - 5 } & Red & Yellow & & 2004 \\
$\mathrm{R} \times \mathrm{R}$ & 133 & 22 & $55: 9$ & 0.0013 & $>0.95$ & $-0.14 \mathrm{NS}$ \\
$\mathrm{R} \times \mathrm{Y}$ & 70 & 36 & $5: 3$ & 0.5659 & $0.50-0.30$ & $1.78 \mathrm{NS}$ \\
$\mathrm{Y} \times \mathrm{R}$ & 51 & 53 & $5: 3$ & 8.0409 & $<0.01$ & 7.4 \\
$\mathrm{Y} \times \mathrm{Y}$ & 0 & 120 & all yellow & 0.0000 & 1 & - \\
\hline & & 2005 & & & \\
$(\mathrm{R} \times \mathrm{Y}) \times \mathrm{Y}$ & 12 & 9 & $11: 9$ & 0.0389 & $0.90-0.70$ & $-0.22 \mathrm{NS}$ \\
$(\mathrm{Y} \times \mathrm{R}) \times \mathrm{Y}$ & 15 & 8 & $11: 9$ & 0.9700 & $0.50-0.30$ & $0.76 \mathrm{NS}$ \\
\hline
\end{tabular}

To confirm the hypothesis, red heads of the red $\times$ yellow and yellow $\times$ red plots were pollinated by yellow-flowered plants. Then, in 2005, 70 progenies of each cross type were transplanted to the experiment field but most of them were unexpectedly destroyed by hares. However, progenies did fit the expected frequencies in between 21 and 23 surviving plants of each cross.

The progeny prediction was based on the expected proportions of 2004 red $\times$ yellow and reciprocal crosses (5:3). Thus, as only red-flowered plants were testcrossed, genotypes would have been 1/5 $A_{1} a_{1} A_{2} a_{2}, 2 / 5 A_{1} a_{1} a_{2} a_{2}$ and 2/5 $a_{1} a_{1} A_{2} a_{2}$. The expected results were $3 / 20$ red : $1 / 20$ yellow for the first genotype and 4/20 red : 4/20 yellow for each of the remaining two genotypes, which gave a final ratio of $11 /$ 20 red : 9/20 yellow plants. Therefore, in spite of the low number of plants that reached flowering time, the numbers observed were close to the expected ones.

There are two subspecies in $H$. petiolaris: H. p. ssp. petiolaris, which usually has purple anthers although they can also be red, and $H$. p. ssp. fallax, whose anthers are red but can also be purple (Rogers et al., 1982). The phenotypic variation between purple and red might be due to different doses of alleles for anthocyanin synthesis, A1 and A2 being the active alleles. In this study, the crosses only involved $H$. p. ssp. petiolaris, as it is the one that seems to be present in Argentina (Poverene et al., 2002). Consequently, the presence or absence of pigment was the only trait under consideration.

Table 2 summarizes different studies of anthocyanin inheritance in cultivated sunflower. Single dominant genes have been described as controlling pigmentation in vegetative and reproductive structures of cultivated sunflower yet modifier genes 
were suggested in three cases. Two or three genes have also been found, with complementary and pleiotropic effects (Table 2).

Table 2: Inheritance of anthocyanin pigmentation in sunflower (Helianthus annuus)

\begin{tabular}{|c|c|c|c|c|}
\hline Plant organ & Gene & Inheritance & Gene action & Reference \\
\hline $\begin{array}{l}\text { Stigma, corolla } \\
\text { and achenes }\end{array}$ & $\begin{array}{l}\text { Single dominant } \\
\text { gene }\end{array}$ & $\begin{array}{l}\text { Segregation } \\
\text { in crosses 3:1 }\end{array}$ & & $\begin{array}{c}\text { Leclercq } \\
1968\end{array}$ \\
\hline $\begin{array}{l}\text { Corolla, stigma } \\
\text { and vegetative } \\
\text { parts }\end{array}$ & $\begin{array}{l}\text { Single dominant } \\
\text { gene }\end{array}$ & & & $\begin{array}{l}\text { Stoenescu } 1974 \\
\text { cited by Miller } \\
\text { and Fick } 1997\end{array}$ \\
\hline $\begin{array}{l}\text { Stems, petiole } \\
\text { and leaf veins }\end{array}$ & $\begin{array}{l}\text { Single dominant } \\
\text { gene }\end{array}$ & $\begin{array}{l}\text { Segregation } \\
\text { in crosses } 3: 1\end{array}$ & $\begin{array}{l}\text { Modifier genes } \\
\text { suggested }\end{array}$ & $\begin{array}{l}\text { Luczkiewics } \\
\qquad 1975\end{array}$ \\
\hline Disc flowers & $\begin{array}{l}\text { Single dominant } \\
\text { gene }\end{array}$ & $\begin{array}{l}\text { Segregation } \\
\text { in crosses } 3: 1\end{array}$ & $\begin{array}{l}\text { Linkage or } \\
\text { pleiotropic effects } \\
\text { suggested }\end{array}$ & Fick 1976 \\
\hline $\begin{array}{l}\text { Ligulated disc } \\
\text { florets }\end{array}$ & $\begin{array}{l}\text { Single dominant } \\
\text { gene }\end{array}$ & $\begin{array}{l}\text { Segregation } \\
\text { in crosses } 3: 1\end{array}$ & $\begin{array}{l}\text { Modifier genes } \\
\text { suggested }\end{array}$ & Mosjidis 1982 \\
\hline Stigmata & $\begin{array}{l}\text { Three dominant } \\
\text { genes }\end{array}$ & $\begin{array}{l}\text { As expected for three } \\
\text { unlinked genes }\end{array}$ & $\begin{array}{l}\text { Cumulative } \\
\text { action }\end{array}$ & $\begin{array}{c}\text { Luczkiewics } \\
1975\end{array}$ \\
\hline $\begin{array}{l}\text { Stigma } \\
\text { and style }\end{array}$ & $\begin{array}{c}\text { Three dominant } \\
\text { genes } \mathrm{Sa}_{1}, \mathrm{Sa}_{2}, \mathrm{Sa}_{3}\end{array}$ & & $\begin{array}{l}\text { Complementary } \\
\text { effect }\end{array}$ & $\begin{array}{l}\text { Skaloud and } \\
\text { Kovacik } 1978\end{array}$ \\
\hline $\begin{array}{l}\text { Stem, leaves } \\
\text { and hypocotyl }\end{array}$ & $\begin{array}{c}\text { Three dominant } \\
\text { genes } \mathrm{T}_{1}, \mathrm{~T}_{2}, \mathrm{Ha}_{4}\end{array}$ & & Id. & \\
\hline $\begin{array}{l}\text { Stigma, } \\
\text { petiole } \\
\text { and leaf }\end{array}$ & $\begin{array}{c}\text { Single dominant gene Ptla } \\
\text { and a second gene in } \\
\text { each organ }\end{array}$ & $\begin{array}{l}\text { Segregation in } \\
\text { crosses 9:7 }\end{array}$ & Pleiotropic gene & $\begin{array}{l}\text { Joshi et al., } \\
\quad 1994\end{array}$ \\
\hline $\begin{array}{l}\text { Stem, petiole } \\
\text { and bract tip }\end{array}$ & $\begin{array}{c}\text { Two dominant genes, } \mathrm{Ptl} \\
\text { and a second gene in } \\
\text { each organ }\end{array}$ & $\begin{array}{l}\text { Segregation in } \\
\text { crosses } 9: 7\end{array}$ & $\begin{array}{l}\text { Complementary } \\
\text { effect and } \\
\text { pleiotropy }\end{array}$ & $\begin{array}{c}\text { Deveraja and } \\
\text { Shanker Goud } \\
2005\end{array}$ \\
\hline
\end{tabular}

However, none of the studied cases segregated as in the $H$. petiolaris crosses, which suggested that disc flower color is controlled by two independent loci showing duplicate gene action. This would produce a 15:1 rather than 9:7 ratio in an $\mathrm{F}_{2}$ generation. As high self-incompatibility precludes obtaining such progenies in $H$. petiolaris, different crosses were attempted in order to study gene segregation. It has been concluded that flower color inheritance in both species follows different patterns. In wild $H$. annuus plants collected in Argentina there is a variable pigment distribution as well as a variable corolla lobe color intensity. This variation consists of different tints of red, but a purple color like $H$. petiolaris was never observed. This could be explained by the segregation of a unique allele pair responsible for anthocyanin synthesis, probably interacting with modifying genes. H. annuus and $H$. petiolaris are diploids but they differ by a minimum of 20 breakages and fusions (Chandler et al., 1986; Rieseberg et al., 1995 and Burke et al., 2004). Chromosome reorganizations could be the origin of the anthocyanin gene duplication in $H$. petiolaris. Gene duplications naturally arise by crossing over and segregation following chromosome rearrangements, as inversions. As linkage maps based on molecular markers are now available in $H$. petiolaris (Burke et al., 2004) it would 
be worthwhile to assign the herein proposed color genes to their respective linkage groups, in order to verify if those groups have undergone structural rearrangements when compared with $H$. annuus chromosomes.

\section{ACKNOWLEDGMENTS}

Thanks are due to National Research Council of Argentina (CONICET) for a fellowship to the first author. This research was supported by grant ANPCYT-PICT 08-9881.

\section{REFERENCES}

Buerkle, C.A. and Rieseberg, L.H., 2001. Low intraspecific variation for genomic isolation between hybridizing sunflower species. Evolution 55: 684-691.

Burke, J.M., Lai, Z., Salmaso, M., Nakazato, T., Tang, S., Heesacker, A., Knapp, S.J. and Rieseberg, L.H., 2004. Comparative mapping and rapid karyotypic evolution in the genus Helianthus. Genetics 167: 449-457.

Carrera, A., Pizarro, G., Poverene, M., Feingold, S., Berry, S. and Leon, A., 2002. Variability among inbred lines and RFLP mapping of sunflower isozymes. Genetics and Molecular Biology 25: 65-72.

Chandler, J., Jan, C.C. and Beard, B.H., 1986. Chromosomal differentiation among the annual Helianthus species. Systematic Botany 11: 354-371.

Covas, G., 1966. Antófitas nuevas para la flora pampeana. Apuntes para la Flora de La Pampa (EEA INTA Anguil) 22: 88.

Desrochers, A.M. and Rieseberg, L.H., 1998. Mentor effects in wild species of Helianthus (Asteraceae). American Journal of Botany 85: 770-775.

Deveraja, T.V. and Shanker, G., 2005. Pleiotropic genes and its influence on stem, petiole and bract tip pigmentation in sunflower (Helianthus annuus L.). Helia 28(43): 107-112.

Fick, G.N., 1976. Genetics of floral color and morphology in sunflowers. The Journal of Heredity 67: 227-230.

Gedil, M.A., Wye, C., Berry, S., Segers, B., Peleman, J., Jones, R., Leon, A., Slabaugh, M.B. and Knapp, S.J., 2001. An integrated restriction fragment length polymorphism-amplified fragment length polymorphism linkage map for cultivated sunflower. Genome 44: 213221 .

Gentzbittel, L., Mestries, E., Mouzeyar, S., Mazeyrat, F., Badaoui, S., Vear, F., Tourvieille de Labrouhe, D. and Nicolas, P., 1999. A composite map of expressed sequences and phenotypic traits of the sunflower (Helianthus annuus L.) genome. Theoretical and Applied Genetics 99: 218-234.

Heiser, C.B., 1947. Hybridization between the sunflower species Helianthus annuus and $H$. petiolaris. Evolution 1: 249-262.

Heiser, C.B., 1961. Morphological and cytological variation in Helianthus petiolaris with notes on related species. Evolution 15: 247-258.

Heiser, C.B., Smith, D.M., Clevenger, S.B. and Martin, W.C., 1969. The North American Sunflowers (Helianthus). Memoirs of the Torrey Botanical Club 22: 1-37.

Imrie, B.C. and Hutton, E.M., 1978. The inheritance of flower color in Macroptilium atropurpureum. The Journal of Heredity 69: 54-56.

Jan, C.C. and Seiler, G.J., 2007. Sunflower. In: Singh R.J. (Eds). Genetic Resources, Chromosome Engineering, and Crop Improvement. Oilseed Crops. CRC Press, Boca Raton, pp. 103-165.

Joshi, S.S., Basavalingappa, S. and Giriraj, K., 1994. Pleiotropy in sunflower (Helianthus annuus L.). Helia 17(20): 1-6.

Leclercq, P., 1968. Hérédité de quelques caractéres qualitatifs chez le turnesol. Annales d'Améliorement des Plantes 18: 307-315.

Leclercq, P., 1969. Une sterilité cyplasmique chez le tournesol. Annales d'Améliorement des Plantes 19: 99-106. 
Luczkiewicz, T., 1975. Inheritance of some characters and properties in sunflower (Helianthus annuus L.). Genetica Polonica 16: 167-184.

Miller, J.F. and Fick, G.N., 1997. The genetics of sunflower. In: Schneiter A.A. (eds) Sunflower Technology and Production, Madison, Wisconsin: American Society of Agronomy, Inc. pp. 441-495.

Mosjidis, J.A., 1982. Inheritance of color in the pericarp and corolla of the disc florets in sunflower. The Journal of Heredity 73: 461-464.

Pahlavani, M.H., Mirlohi, A.F. and Saeidi, G., 2004. Inheritance of flower color and spininess in safflower (Carthamus tinctorius L.). The Journal of Heredity 95: 265-267.

Poverene, M.M., Cantamutto, M.A., Carrera, A.D., Ureta, M.S., Salaberry, M.T., Echeverria, M.M. and Rodriguez, R.H., 2002. El girasol silvestre (Helianthus spp.) en la Argentina: Caracterización para la liberación de cultivares transgénicos. Revista de Investigaciones Agropecuarias RIA 31: 97-1 16.

Poverene, M., Carrera, A., Ureta, S. and Cantamutto, M., 2004. Wild Helianthus species and wild-sunflower hybridization in Argentina. Helia 27(40): 133-142.

Rieseberg, L.H., Van Fossen, C., Arias, D. and Carter, R.L., 1994. Cytoplasmic male sterility in sunflower: Origin, inheritance, and frequency in natural populations. The Journal of Heredity 85: 233-238.

Rieseberg, L.H., Van Fossen, C. and Desrochers, A.M., 1995. Hybrid speciation accompanied by genomic reorganization in wild sunflowers. Nature 375: 313-316.

Rieseberg, L.H., Kim, M.J. and Seiler, G.J., 1999. Introgression between the cultivated sunflower and a sympatric wild relative, Helianthus petiolaris (Asteraceae). International Journal of Plant Science 160: 102-108.

Rogers, C.E., Thompson, T.E. and Seiler, G.J., 1982. Sunflower Species of the United States. National Sunflower Association, Fargo, ND pp. 75.

Skaloud, V. and Kovacik, A., 1978. Survey on inheritance of sunflower characters which are conditioned by a small number of genes. In: Proc. $8^{\text {th }}$ Int. Sunflower Conf., Minneapolis, MN, International Sunflower Association, Paris, France. pp. 490-496.

Sreevalli, Y., Kulkarni, R.N. and Baskaran, K., 2002. Inheritance of flower color in periwinkle: orange-red corolla and white eye. The Journal of Heredity 93: 55-58.

Wilson, V.E. and Hudson, L.W., 1978. Inheritance of lentil flower color. The Journal of Heredity 69: 129-130.

\section{HERENCIA DEL COLOR DE LAS FLORES DEL DISCO EN Helianthus petiolaris}

\section{RESUMEN}

En Helianthus petiolaris (Asteraceae) las flores del disco son generalmente rojo púrpura debido a los pigmentos de antocianina en los lóbulos de la corola, estilo y estigma. Sin embargo, de vez en cuando se encuentran plantas con flores amarillas. La herencia de este rasgo fue estudiada a través de cruzas entre diversos fenotipos y los resultados indicaron que el color de la flor es controlado por dos genes con acción complementaria, ambos loci son dominantes y de herencia independiente. Esto está de acuerdo con resultados obtenidos en girasol cultivado, $H$. annuus donde de uno a tres genes dominantes se han propuesto para la expresión de la antocianina en diversos órganos.

\section{HÉRÉDITÉ DE LA COULEUR DES FLEURS DU DISGUE DANS Helianthus petiolaris}

\section{RÉSUMÉ}

Dans Helianthus petiolaris (Asteraceae) des fleurs du disque sont en général de couleur rouge violacé à cause des pigments anthocyaniques dans les 
lobes de la corolle, le style et le stigmate. Cependant, on peut trouvé occasionnellement des plantes avec des fleurs jaunes. L'hérédité de ce caractère a été étudiée à travers de croissements entre différents phénotypes et les résultats ont indiqué que la couleur des fleurs est controllée par deux gènes avec une action complémentaire. Ces résultats sont en accord avec ceux obtenus dans le tournesol cultivé, $\mathrm{H}$. annuus pour lequel de un à trois gènes ont été proposés pour l'expression des anthocyans dans des organes differents. 